\title{
Inflammatory Tinea Capitis Mimicking Erosive Pustulosis of the Scalp
}

\section{Tinha Inflamatória Mimetizando uma Pustulose Erosiva do Couro Cabeludo}

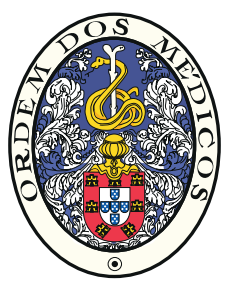

Francisca ALVES $\triangle^{1}$, Mariana BATISTA ${ }^{1}$, Margarida GONÇALO ${ }^{1,2}$

Acta Med Port 2019 Nov;32(11):733-733 - https://doi.org/10.20344/amp.11588

Keywords: Alopecia; Scalp Dermatoses; Tinea Capitis

Palavras-chave: Alopecia; Dermatoses do Couro Cabeludo; Tinha do Couro Cabeludo
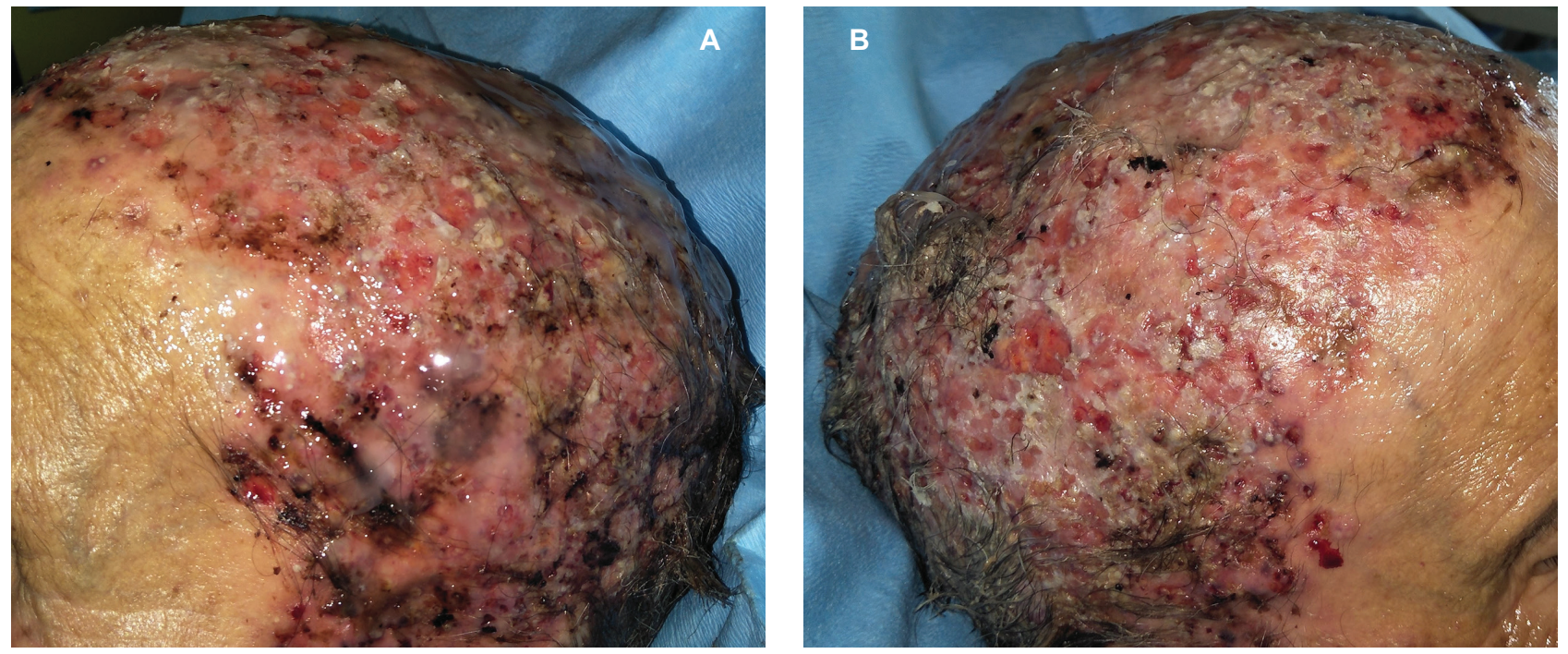

Figure 1 - Extensive crustal lesions covering the entire scalp (A, B), with erosive and exudative areas

Tinea capitis is a common dermatophytosis in paediatric patients seldom observed in adults. ${ }^{1,2} \mathrm{~A}$ rarer and often underdiagnosed subtype is the inflammatory form, which causes a severe local inflammation and usually leads to local scarring alopecia. ${ }^{2}$

We report the case of a 92 year-old-woman with a 3-month history of extensive painful crusts covering the entire scalp, with purulent and erosive areas and a foul-smelling exudate, unresponsive to oral antibiotics and topical steroids (Fig. 1).

Cutaneous biopsy revealed numerous spores and

\section{PROTECTION OF HUMANS AND ANIMALS}

The authors declare that the procedures were followed according to the regulations established by the Clinical Research and Ethics Committee and to the Helsinki Declaration of the World Medical Association.

\section{DATA CONFIDENTIALITY}

The authors declare having followed the protocols in use at their working center regarding patients' data publication.

\section{PATIENT CONSENT}

Obtained.

\section{CONFLICTS OF INTEREST}

All authors report no conflict of interest. hyphae within the hair follicles with parasitism of the hair shaft. Microscoporum audouinii was isolated from the hair and the cutaneous biopsy. Unfortunately, the patient died suddenly due to pneumonia and acute congestive heart failure, and we were unable to start appropriate treatment with oral antifungals. Inflammatory tinea of the scalp is an uncommon entity in current clinical practice, and exceptionally rare in adults. However, it needs to be considered, namely in the differential diagnosis of erosive pustulosis of the scalp ${ }^{3}$ which may have similar lesions and also affects older patients.

\section{FUNDING SOURCES}

This research received no specific grant from any funding agency in the public, commercial, or not-for-profit sectors.

\section{REFERENCES}

1. Elewski B. Tinea capitis: a current perspective. J Am Acad Dermatol. 2000;42:1-20.

2. Williams J, Honig P, McGinley K, Leyden J. Semiquantitative study of tinea capitis and the asymptomatic carrier state in inner-city school children. Pediatrics. 1995:96:265-7.

3. Noé C, Grob JJ, Choux R, Bonerandi JJ. Pustulose érosive du cuir chevelu. Une dermatose pustuleuse spongiforme?. Ann Dermatol Venereol. 1993;120:693-5.

\footnotetext{
1. Serviço de Dermatologia. Centro Hospitalar e Universitário de Coimbra. Coimbra. Portugal.

2. Departamento de Dermatologia. Faculdade de Medicina. Universidade de Coimbra. Coimbra. Portugal.

$\square$ Autor correspondente: Francisca Alves. francisca.alves37@gmail.com
}

Recebido: 21 de novembro de 2018 - Aceite: 13 de dezembro de 2018 | Copyright @ Ordem dos Médicos 2019 